This is the peer reviewed version of the following article: Rekret, Paul and Choat, Simon (2016) From political topographies to political logics : post-Marxism and historicity. Constellations: An International Journal Of Critical And Democratic Theory, 23(2), pp. 281-291, which has been published in final form at http:// dx.doi.org/10.1111/1467-8675.12199. This article may be used for non-commercial purposes in accordance with Wiley Terms and Conditions for Self-Archiving. 


\title{
From Political Topographies to Political Logics: Post-Marxism and Historicity
}

\author{
Paul Rekret \\ Richmond American University in London \\ Queen's Road \\ Richmond-Upon-Thames \\ Surrey \\ TW10 6JP \\ Email: rekretp@richmond.ac.uk

\section{Simon Choat} \\ Kingston University \\ Penrhyn Road \\ Kingston upon Thames \\ Surrey \\ KT1 2EE \\ Email: s.choat@kingston.ac.uk
}

\begin{abstract}
This paper engages with the question of the historical and ontological status of the logics of hegemony articulated by Ernesto Laclau. It interrogates the concept of real abstraction that Laclau mobilises to explain the historical status of his theory. It is argued that while Laclau grounds his conceptual system in an ontology of generalised antagonism, this is done to the exclusion of formally conceiving the historical conditions of those logics. The paper demonstrates that it is the irreducible gap between reflection on historical and ontological conditions of possibility from which the most pervasive critiques of Laclau's work are derived. In turning to the work of Alfred SohnRethel, the paper suggests a different conception of real abstraction, one which locates the sources of abstraction in the division of mental and manual labour. In drawing on the Marxist analysis of real abstraction and the division of labour, the essay seeks to deflate the subsumption of politics to ontology and to turn attention to the logics which condition the possibility of social struggle today namely, the logics of contemporary capitalism.
\end{abstract}

Keywords: Ernesto Laclau; Alfred Sohn-Rethel; real abstraction; political ontology; post-Marxism 


\section{Introduction: From Marxist Topographies to Post-Marxist Logics}

No other thinker is more closely associated with the theoretical paradigm of 'post-Marxism' than Ernesto Laclau. Central to Laclau's work, and to post-Marxism more broadly, is an articulation of collective social struggle in opposition to vulgar materialist and orthodox Marxist topographical conceptions of the political wherein legal, political, and ideological superstructures are read off and categorised according to the way they reflect the terms of an infrastructural economic level. While emerging from and drawing upon a Marxist heritage, post-Marxist political theories tend to locate the sources and conditions of social struggle and emancipation within some axiomatic, irreducible principle or kernel of contingency, agency or subjectivity (generally inscribed in an ontological register) which functions as the guarantor or promise of the possibility of social struggle. Accordingly, the tendency is to draw a binary between the properly political moment or principle indexed by notions of 'event', 'antagonism', 'equality', 'multitude', or 'singularity' - and the juridical, regulative, disciplinary or administrative order of everyday politics which it disrupts. ${ }^{\mathrm{i}}$ Such articulations of the terrain of political theorising upon the purity of some political principle or notion of 'event' have sought to sustain the possibility of collective struggle in an epoch of class decomposition and defeat for the post-1968 Left, but in doing so, they have (perhaps unwittingly) produced their own aporias. First, the possibility of meaningful social transformation is sustained but at the cost of divorcing the concept of the political from any critique of political economy and from the quotidian work of political organising, analysis, and even conciliation. A second, more profound problem relates to the first, for insofar as the political is analytically distinguished and separated from every determinate order, the historicity of the concept of 'the political' itself is not interrogated. A circularity is introduced, in which the political is affirmed in terms of some sui generis principle which is itself never situated politically or related to its own historical conditions. ${ }^{\text {ii }}$

This article investigates this aporia of historicity as it exists in Laclau's work. Investigating Laclau's work in terms of this problematic permits us to evaluate his own contribution to recent debates in emancipatory political theory and provides an analysis of the limitations of Laclau's response to some pervasive theoretical problems. In particular, this article interrogates Laclau's mobilisation of the concept of 'real abstraction' in his attempt to resolve the conceptual impasse described above. In doing so it confronts Laclau with a materialist conception of abstraction, exemplified in this case by the work of Alfred Sohn-Rethel. While restricting our account to Sohn-Rethel will involve amputating fecund debate and dialogue over materialist accounts of the conditions of conceptual 
abstraction, we justify doing so insofar as it serves our aim of interrogating Laclau's negotiation with questions central to much recent political theorising. ${ }^{\text {iii }}$

Laclau has sought to negotiate the vicious circularity between his ontological conception of the political and its historicity by relating his own post-Marxist theory of generalised antagonism to certain historical transformations, in particular the change from a Fordist to a post-Fordist mode of production. For Laclau, the emergence of a 'globalised' or 'disorganised' capitalism and the proliferation of social actors around new social movements reveal not only the limitations of orthodox Marxism, but also and more fundamentally the fact that there is never any immutable essence to society and that social identities are always politically constituted. ${ }^{\text {iv }}$ On the basis of his diagnosis of the present Laclau rejects a topographical understanding of the social - in which one level of the social structure (such as its economic base) explains all the other levels - in favour of his own logics of hegemony. Laclau claims that to shift the scope of the analysis from an orthodox topography to the terrain of logics is not to move to a merely descriptive account of the agents and processes involved in the formation and dissolution of collective identities but to a 'formal analysis' of their conditions. ${ }^{v}$ In response to the question of the historical and political status of his own ontology, Laclau has argued that he conducts a formal analysis of 'abstractions' towards which the real itself tends:

'[f]ormal analysis and abstraction are essential for the study of concrete historical processes - not only because the theoretical construction of the object is the requirement of any intellectual practice worthy of the name, but also because social reality itself generates abstractions which organise its own principles of functioning. Thus Marx, for instance, showed how the formal and abstract laws of commodity production are at the core of the actual and concrete workings of capitalist societies. In the same way, when we try to explain the structuration of political fields through categories such as 'logics of equivalence,' 'logics of difference' and 'production of empty signifiers,' we are attempting to construct a theoretical horizon whose abstractions are not merely analytical but real abstractions on which the constitution of identities and political articulations depends. ${ }^{\text {vi }}$ 
This article will argue that Laclau's theoretical mobilisation of the notion of real abstraction in response to the issue of the historicity of his political ontology is philosophically problematic at best and politically disabling at worst. It will demonstrate that an irreducible tension exists between Laclau's account of the historical conditions of the logics he derives from the 'real' and the political ontology he articulates as emerging from out of these logics. It then contrasts what it takes to be Laclau's intellectual conception of real abstraction with a materialist account of intellectual abstraction as it is articulated by the thinker most often associated with the term, namely SohnRethel. ${ }^{\text {vi }}$ By drawing on Sohn-Rethel's deployment of the Marxian conception of abstraction, we seek to inform an understanding of philosophical and political abstractions which does not seek to subsume the latter to a political ontology but, rather, seeks to historicise and politicise the separation of cognitive and material practice. Finally, it will be argued that by politicising the very activity of abstraction, the materialist conception of real abstraction informs and also supports political theorising which seeks to think the conditions of both political concepts and social struggle in the changing and nebulous logics of contemporary capitalism, without limiting itself to the a priori terms of a political ontology or hypostatisations of political subjectivity. We start with a brief overview of Laclau's central arguments and concepts.

\section{Post-Marxist Logics and the Ontology of Generalised Antagonism}

The fundamental starting point for Laclau's political theory is an ontological presupposition: the presence of an 'antagonistic frontier' within systems of social relations is irreducible; no regime or social order is possible without some antagonistic 'other' or difference which it expels in its selfconstitution. That is, no social order or collective subject can assume a state of objectivity or selfidentity since every such order is founded upon an 'infinitude' which entails that it will always be, in part, exclusive as much as inclusive so that its dislocation and concordant contingency is irreducible. Given that every social order is ultimately limited or 'threatened' insofar as it cannot master the infinite possibilities for social antagonism which it seeks to contain, contingency or 'dislocation' is, Laclau argues, irreducible. This irreducibility, he argues, signals the primacy of an 'ontological

dimension' which is 'foundational' to every concrete social order and which Laclau calls simply, 'the political'. ${ }^{\text {viii }}$ The import of this political ontology for Laclau's theory becomes apparent once we begin to unpack the conceptual architecture he builds upon it. 
The basic element of Laclau's conceptual apparatus, the 'social demand', and the logics that he derives from it are grounded in his ontological presuppositions. ${ }^{\text {ix }}$ For Laclau, the meaning of any anti-systemic 'social demand' is always split between what he calls its particular dimension and its universal dimension. That is to say, insofar as they all bear an anti-systemic meaning, a series of particular demands may be united into some broader, more universalising claim which unites them and so constitute what Laclau calls a 'chain of equivalence'. As chains of equivalence are extended to encompass more and more particular demands, one particular demand - known as the 'empty signifier' - has to assume the role of representing the chain as a whole. Take for example the transformation of Solidarność which begins as the 'particular' demand of local dockworkers in Gdansk. As the movement broadens to encompass other demands against the communist regime, the particular meaning of Solidarność is gradually 'emptied' in order for it to take on a relatively universal character. Moreover, the other particular demands which join under its banner (of students, the intelligentsia, etc.) also have to take on some of the universal character of the movement and thus be 'split' from their particularity. As increasingly heterogeneous demands are embraced by an equivalential chain, the less its 'empty signifiers' are attached to their original particular demand, and a relative universality prevails over the expression of particularity. ${ }^{\mathrm{x}}$ Similarly, other links in the chain are also split between their particular demand and the universal signification that they acquire within the equivalential chain. What Laclau calls the logics of hegemony are precisely these operations in the social field whereby particularities take up a universal signification and, thus, permit the articulation of relatively collective subjects (as exemplified by the ultimately broad social base encompassed by Solidarność at its peak).

This is not all, however. Regimes themselves may also engage in hegemonic or equivalential operations and thus potentially absorb some oppositional demands. In such cases the 'antagonistic frontier' between equivalential chains is destabilised insofar as the link which connects some particular demands to a broader equivalential relation is broken (as might occur if bosses met the demands of some striking workers and not others, thus breaking their unity). This entails that while 'logics of equivalence' universalise demands by making them all bearers of a meaning which transcends their particularity, they are opposed by 'logics of difference' wherein demands are particularised and their equivalential or universalising potential is neutralised. ${ }^{\mathrm{xi}}$ In such situations wherein an 'antagonistic frontier' is destabilised insofar as some of its elements are particularised, the latter never remain purely particular, but enter into different sets of equivalences. In this case, either 
a struggle for different conceptions of universality occurs or, alternatively, a chain is extended to encompass those other conceptions of universality (our striking workers might form a new trade union that encompasses a broader set of demands, for example). ${ }^{\text {xii }}$ Given the existence of a plurality of discursive strategies in the same discursive space, the meaning of particular demands may become indeterminate so that they may become simultaneously part of different and even competing equivalential chains. These signifiers, which Laclau calls 'floating', have an emptiness which results from the multiple discourses interpreting them in relation to different terms. The concept 'woman', employed as it is by groups on both the left and the right, or by feminists and anti-feminists, to support widely opposing claims is exemplary of such a 'floating' signifier.

How does this formalist account of social logics hinge upon and reinforce Laclau's ontological claim for the constitutive status of antagonism? Since it is impossible for an equivalential chain to incorporate into itself all possible particular demands or to absorb any particular demand in all its heterogeneity, the implication is that no social order can transcend the particularities or differences which form it. No regime or collective struggle can ultimately master the multitude of demands which ultimately come together under its banner and, accordingly, can never claim any ultimate finality, objectivity, or totality. Conversely, unconstrained access to what Laclau sometimes calls the 'radical outside' beyond any equivalential chain or social order to a realm of pure particularities or differences is foreclosed since such access would imply transcending all social order and would thus itself repeat the totalising move which has already been barred. For Laclau, what he calls the 'mutual subversion' between the contingent and the necessary or between any 'concrete social order' and the 'function of ordering' entails both the irreducibility and the 'primacy' of the political conceived as a generalised ontological terrain of antagonism. xiii That is, according to the logics of hegemony, subversion and antagonism are an irreducible element of all social order.

This deconstructive vision of the political is intended to provide sustenance for social struggle insofar as it displaces an orthodox Marxist topographical principle of intelligibility of the social with the social logics of hegemony. Laclau argues that social antagonism cannot be read off from some economic base which determines a political, juridical, or ideological superstructure: we cannot decide whether a given conjuncture is 'reformist' or 'revolutionary' by locating it within a system of topographical locations determined by a subterranean infrastructure. Conceived in terms of the logics of variable articulations of equivalence and difference in Laclau's theory, social antagonism 
cannot be determined by some more fundamental level or positivity and hence cannot be made epiphenomenal to some process beyond it. Thus, for instance, any antagonistic relation between workers and capitalists cannot be derived from some schema of the relations of production but would require something exterior to them, such as the worker's identity as a consumer. ${ }^{\text {xiv }}$

Laclau seems to claim that this shift from a topographical principle to a social logics is emancipatory for two central reasons. First, because within his schema the subject of social struggle is neither determined nor limited in advance. Secondly, this implies that the locus or object of struggle is similarly contingent. In short, given the irreducible contingency at the heart of every social order or regime, social struggle is indeed irreducible. Yet if Laclau thus affirms and seeks to sustain social struggle as an inherent possibility of any social order, this begs the question of whether the logics of hegemony, by which he formalises this possibility, themselves have a historical character? If he fails to affirm their historicity then he is caught asserting the sort of transcendent, metaphysical principle his own theory disallows. On the other hand, if he posits the logics of hegemony as tied to particular historical conditions he implicitly places limitations upon the conception of antagonism and so would undermine the primacy he accords to the political and the concordant contingency upon which his account relies. It is to a further investigation of this problem to which we now turn.

\section{Post-Fordism and Post-Foundationalism}

While Laclau's conception of generalised antagonism forms the ontological conditions for the emergence of the logics of hegemony, he has theorised their historical conditions (or what he often calls 'terrain') in terms of the structural transformation from Fordist to post-Fordist production, and in particular the decentering of power in a 'globalised world' wherein agents' identities are 'constitutively overdetermined'. ${ }^{x v}$ Given these historical transformations, he argues that the relations of production have lost their centrality in determining political identity, while instead, differential identity logics (of race, gender, etc.) increasingly constitute political identities which do not overlap with class positions. ${ }^{\text {xvi }}$ Drawing upon the Marxist conception of capitalism as a dislocatory force divesting us of our illusions, Laclau argues that we have been relieved of the topographical illusion

of economic determinism and become aware of the contingency underlying political categories that we once took to be necessary. In place of an orthodox Marxist topography in which political 
struggles are determined by an economic infrastructure, he invokes an increased awareness of the historicity and contingency of discourses and the unevenness of power relations. ${ }^{\text {xvii }}$

But it is at this point that we might return to the question we have put to Laclau regarding the historicity of his categories. What exactly is the relationship between, on the one hand, generalised antagonism as ontological condition of the 'real abstractions' of which logics of hegemony are the formal articulation and, on the other hand, the historical conditions which form the terrain of these abstractions? Do the historical transformations of late capitalism reveal an always latent 'foundational' ontology of generalised antagonism? If so, then Laclau is caught positing the sort of ahistorical a priori that his own theory of the political forecloses. However, if he admits their historicity then he would have to either admit, as critics have argued, that his concepts merely reflect the conditions of late capitalism or reassert some account of the conditions of the logics of hegemony. ${ }^{\text {xviii }}$

When pressed by interlocutors regarding the historicity of his own categories, Laclau has refused either to set up the logics of hegemony as transcendental categories (since this would mark them as a-historical) or to affirm their absolute situatedness (since this would amount to sneaking in some other 'meta-theoretical' framework of historicity, itself assuming a transcendental status). Rather, Laclau's solution has been to draw a strict category distinction between the ontological and historical conditions of hegemonic logics, and to exclude the possibility of a formal historical account from out of the logics of hegemony themselves: 'the very logic of empty signifiers has a genealogy of its own - although its formal possibility can be abstractly determined, its historical actualisation depends on conditions that are not derivable from that possibility' ${ }^{\text {xix }}$

But if the historical conditions of these logics cannot be derived from those logics themselves then Laclau can only assert, as he rightly does, their contingency and historicity - but at the same time, he must, in his words, 'renounce any attempt to grasp the meaning of its historical variation conceptually'. In other words, if he is to remain coherent, Laclau is limited to affirming, in his words, the 'finitude' of his system of categories. ${ }^{\mathrm{xx}}$ While this affirmation of finitude maintains the logical consistency of his system, it lies in fundamental tension with his own sociological account of its historical conditions. That is, his ontological claim explicitly relies upon a historical narrative of the gradual decline of the centrality of working-class identity as a result of structural changes to 
relations of production in globalised capitalism, which in turn functions as the ground for shifting the terms of analysis from topography to logics. Consequently, structural or historical conditions cannot ultimately be addressed by the logic of Laclau's system insofar as they are formally excluded by the ontological conditions of discursive logics. If those discursive logics were to admit the historical conditions, it would amount to an affirmation of a historical logic in excess of the ontology of generalised antagonism.

This tension between history and ontology in Laclau's work is frequently on display in some of his seemingly contradictory articulations. For example, in one text we can find Laclau refusing the possibility of any meta-discursive objectivity, claiming that any objectivity is itself necessarily discursively constructed since, given his political ontology, 'antagonism is the limit of all objectivity'. ${ }^{\text {xi }}$ Yet a few pages later he proclaims that it is without a doubt true that the phenomenon of commodification is at the heart of the multiple dislocations of traditional social relations'. ${ }^{x i i}$ Or again, in another text, while affirming his political ontology Laclau nevertheless appeals to 'an analysis of the objective tendencies undermining [notions such as class struggle]' to support his narrative of the historical emergence of generalised antagonism. ${ }^{\text {xiii }}$

As we noted above, Laclau has sought to justify this oscillation between the ontological and the historical or sociological by drawing on the Marxist concept of 'real abstraction'. Hegemonic logics, he argues, are 'forms of structural determination which are context-specific' insofar as they are real abstractions, that is, 'an abstract which is not a formal dimension proceeding or separate from the concrete, but something to which the concrete tends. In support of his claim to maintain both the historicity and the ontological status of his theory Laclau gives three analogical examples of such 'concrete abstracts' in order to defend his notion of a concept which emerges upon a particular historical terrain yet which transcends these temporal boundaries: the Marxian concepts of labor and of the commodity-form, and the concept of human rights. ${ }^{x i v}$ All three concepts, he argues, function analogously to his own account of the logics of hegemony since they can only emerge with particular historical developments yet come to have analytical purchase and produce concrete effects upon the world.

The problem here hinges upon Laclau's use of the notion of real abstraction. As we will argue in more detail below, in the Marxist notion of real abstraction social relations are mediated by abstract 
logics. Both the examples of abstract labor and of the commodity-form imply that the process of abstraction is operative in the world, anterior or a priori to abstractions in thought. In this materialist notion of real abstraction, as Fredric Jameson puts it, "we can think abstractly about the world only to the degree to which the world itself has already become abstract." ${ }^{x x v}$ Conversely, in the case of human rights there is an abstraction from real inequalities or differences to produce a generic concept of personhood: the formal subject of rights is an a posteriori intellectual or even ideological abstraction from a real person. A similar inversion or intellectual abstraction occurs in the course of Laclau's presentation of the logics of hegemony. That is, these logics are imposed upon social reality by the intellectual act of the theorist and in turn produce insights that are then taken as evidence for the nature of social being as such. The abstraction from the content of particular social struggles or demands does not occur in practice but in an a posteriori imposition of mental logic upon the world. While we will examine the implications of taking up either intellectual or materialist notions of abstraction further below, let us assert at this point that Laclau's reference to the concept does not rescue him from the problem of the historicity of his categories. In fact, in drawing upon an intellectual conception of abstraction his dilemma is not unlike that of the idealist defence of human rights, inevitably caught oscillating between defending the universality of rights while affirming the historical and cultural specificity of their origins. .xvi $^{\text {. }}$

Laclau seeks to deflate any "objectivist" historical claims that his use of the notion of real abstraction might imply by reference to the Marxian notion of "tendency" yet this merely shifts the weight of the claim back to the tension between Laclau's account of structural historical transformations and his account of the logics of hegemony. That social actors and movements have undergone transformation in recent decades is without question. However, the interpretation of those changes offered by Laclau, whether tendential or complete, relies upon a meta-discursive historical logic that his ontology prohibits. In short, whatever descriptive salience Laclau's logics of hegemony might have, they hold no explanatory power since their conditions are theorised not as historical but, through the imposition of an intellectual abstraction, as ontological.

What are the political effects of this irreducible tension between ontology and history in Laclau's work? While Laclau has sought sustenance for social struggle in the contingency of the social order it seeks to reveal, in failing to satisfactorily connect those theoretical claims to historical or sociological ones, the outcome seems in fact to mark a retreat from any meaningful engagement 
with the problems, strategies and negotiations which any social struggle must face. This is apparent in the two most prevalent and enduring criticisms of Laclau's work.

First and most prevalent is the charge of idealism, made most infamously by Norman Geras in his review of Hegemony and Socialist Strategy. The claim here is that Laclau's denial of any division between the discursive and extra-discursive amounts to a rejection of a 'pre-discursive reality and an extratheoretical objectivity' ${ }^{\text {xxii }}$ This amounts, it is argued, to a denial of objective reality as such, and hence to philosophical idealism. In response to this charge Laclau has insisted that his deconstruction of the division between the discursive and extra-discursive is neither idealist nor relativist, since the presumption that the meaning of an object is always discursively constructed does not exclude the possibility that an object can exist independently of thought: it implies merely that the 'meaning' or being of an object will always be constituted within a particular discursive horizon. ${ }^{\text {xviii }}$ Accordingly, Laclau's rebuttal to the charge of idealism is premised upon two related claims: that discourses are themselves material practices; and that if idealism is defined as a 'reduction of the real to the concept' then the category of the discursive escapes the charge, since the irreducibility of antagonism prohibits access to objective reality. ${ }^{\text {xix }}$

While a generous reading of Laclau might argue that such a claim formally undermines the charge of idealism, it nevertheless fails to respond fully to his critics, since it does not address the question of the historical conditions of discourse or, more specifically, of particular discourses. For if materialism is defined in part by the irreducibility of the real to the concept, it is usually also defined as reflection upon the nature and mechanisms of the realities from which thought emerges. ${ }^{\text {xxx }}$ Such a reflexive mechanism is absent from Laclau's theory insofar as the political ontology of generalised antagonism formally excludes an account of the historical conditions of hegemonic logics. This leaves Laclau with the meta-theoretical problem we described above: he appears unable to account for what he views as the historical shift from a topographical to a logical analytics of the social within the terms of the logics of hegemony. Moreover, in strictly political terms he is unable to provide more than purely formal criteria for explaining why particular logics become hegemonic. Given that there is no scope in the theory for an account of discursive transformations, it has been argued that Laclau's system displaces any explanation of the emergence of particular demands or struggles for their discursive interpretation. ${ }^{\mathrm{xxi}}$ 
The second major criticism of Laclau concerns the emancipatory potential of his work. In anchoring his conception of logics upon the ontological category of the founding moment of society to the formal exclusion of history, Laclau's political theory also locates this moment - the contingent antagonistic limit which guarantees the contingency of any social order or identity - as the essential moment of any emancipatory politics. As a number of scholars have persuasively claimed, this ostensibly 'radical' gesture disables in advance the pursuit of truly emancipatory collective acts: any collective political gesture will be blind to its conditions of possibility and so may lead to a politics of cynical resignation. ${ }^{\text {xxii }}$ It is in this sense that we can situate Laclau's claim that if, following the analytical shift from topography to logics, there is nevertheless a conception of 'false consciousness' to be maintained, it is insofar as ideological misrecognition be re-defined as the failure to affirm the particularity and situatedness of any claim to universality. ${ }^{\text {xxiii }}$ Once political theory is conceived in terms of the critical demand for recognition of the ontological facticity of antagonism and of contingency as constitutive of social relations, it functions to bracket politics itself insofar as it seems to exclude working through the particular nature of antagonistic relations or the lack thereof today. ${ }^{\text {xxiv }}$ In short, the limits of the explanatory power of Laclau's theoretical categories lie in the way in which the 'real' of his abstractions is to be conceived. Insofar as the conditions of abstraction are exclusively located in ontology to the formal exclusion of historical analysis, political theory is at best relatively inflexible and uninformative or, at worst, disabling of political struggle.

\section{Real abstractions}

We have shown that Laclau's work is marked by a tension between its ontological and its historical claims. Sometimes it seems as if his ontology of generalised antagonism is somehow a-historical. But such a position would clearly be problematic, from both a theoretical and a political perspective: not only would it risk reliance on the kind of foundational ontology that Laclau putatively rejects, it would seem unable to account for the historical and social conditions that he does link to his ontology, and unlikely to inspire concrete political engagement with those conditions. Elsewhere, in contrast, Laclau emphasizes the particular historical conditions from which his logics emerge. But this brings its own problems: there is a circularity in referring an ontology to historical conditions whose own ontological status is not specified, and it raises the suspicion that such a logics would be merely the passive reflection of their conditions rather than offering critical purchase or wider application. Oscillating between these two positions, there seems in Laclau's work to be a gulf between the ontological and the historical. 
Laclau's way of bridging this gulf is by calling upon the notion of real abstraction: the abstractions of his logics of hegemony (he claims) are real insofar as they are that towards which the concrete tends. He cites the notion of real abstraction in his attempt to develop abstract concepts which are connected to a particular historical context yet which nonetheless transcend that context and attain wider application. Yet in Laclau's hands, real abstraction does not do the job required. His 'real abstractions' are ultimately intellectual abstractions from chosen historical 'tendencies'. Such an approach merely reformulates the impasse already identified: either the ontological status of those historical tendencies themselves remains unexplained; or the ontological abstractions float free of the historical tendencies from which they are supposedly drawn.

That the problem here is not the notion of real abstraction itself but its specific use by Laclau is made clear if we examine a materialist conception of real abstraction. We shall now turn to the work of the thinker who has done most to elaborate this notion: the critical theorist Alfred Sohn-Rethel. While this account leads us to curtail analysis of the critical reception of Sohn-Rethel's work and cut off broader dialogue with alternative materialist accounts of the sources of mental abstractions, drawing upon Sohn-Rethel will nonetheless permit us to develop an account of real abstraction which neither reduces politics to ontology nor reduces ontological abstractions to some unexamined historical base..$^{\mathrm{xxv}}$

While Laclau focuses on the abstractions that might be derived from the tendencies of contemporary political discourses, Sohn-Rethel focuses on the more fundamental question of the conditions of abstraction as such. Accordingly, whereas Laclau's work is undermined by a rupture between his ontology and the historical and political conditions of that ontology, the materialist understanding of real abstraction seeks to account for this rupture itself by locating the conditions of cognitive abstractions in historical and material practices, specifically in the division between mental and manual labour. Hence not only does the materialist conception avoid the division between ontology and history that marks Laclau's work, it aims to explain the occurrence and persistence of this very division in modern thought.

Sohn-Rethel's goal is to provide a historical and materialist explanation of different forms of consciousness. He does so by analysing the emergence of philosophical thought in Greece, the birth 
of modern science with Galileo, and Kant's a priori, accounting for these intellectual developments in terms of the division of mental and manual labour that (according to Sohn-Rethel) characterizes all class societies. ${ }^{\text {xxvi }}$ His work hinges upon a materialist demonstration that cognitive categories reflect particular historical human practices - hence the subtitle of his magnum opus Intellectual and Manual Labour: A Critique of Philosophical Epistemology. Although he is a Marxist who frames his book as an enquiry into the relationship between base and superstructure, we believe that Sohn-Rethel's methodology provides the resources necessary to move beyond a topographical schema. ${ }^{\text {xxvii }}$ Rather than viewing conceptual abstractions merely as a superstructural epiphenomenon of an underlying economic base, Sohn-Rethel begins from forms of consciousness and then infers what kind of society could have produced these forms. Hence his question is not: given this economic base, or this particular set of historical conditions, what kinds of thought should we expect? But, rather: given these concepts and truths, what must have been the conditions that gave rise to them?

Laclau ultimately fails to connect the ontological and the historical because his notion of real abstraction maintains the divide between them: his ontological concepts are (at most) intellectually abstracted from historical tendencies (or, at worst, basically unrelated to them). For Sohn-Rethel, in contrast, the real abstractions in which thought abstractions are rooted are abstractions that take place not merely in our minds, but in our actions and practices, originating outside of thought. It is in this sense for Sohn-Rethel that 'abstraction precedes thought. ${ }^{\text {xxviii }}$ Instead of abstracting from historical conditions, Sohn-Rethel begins with our thought abstractions and traces them back to real abstractions. In this way, rather than relying on an ontology whose historical conditions cannot be formulated - as Laclau does - Sohn-Rethel can provide a socio-political analysis that can grasp its own conditions. We shall examine Sohn-Rethel's arguments in more detail, before demonstrating why and how his work can help us develop a political logics that neither depends upon a topographical analysis nor subsumes politics into ontology.

\section{The Historical Origins of Abstraction}

Locating our thought abstractions in the real abstractions of material practices allows Sohn-Rethel both to acknowledge the non-empirical nature of those thought abstractions and to relate them to historical conditions. The key real abstraction that Sohn-Rethel identifies is that of commodity exchange. The real abstraction of commodity exchange effects what he calls a 'social synthesis'. This refers to 'the network of relations by which society forms a coherent whole' - or, in other words, 
what holds a society together. ${ }^{\text {xxix }}$ Different social syntheses give rise to different forms of consciousness or thought: 'the socially necessary forms of thinking of an entire epoch are those in conformity with the socially synthetic functions of that epoch' ${ }^{\mathrm{xl}}$ In pre-class societies, the social synthesis is effected by communal production. There is no division between intellectual and manual labour, but rather a '[s]ocial unity of head and hand', in that there is collective control over the direction of labour: those who labour direct their own labour. ${ }^{\text {xli }}$ In 'societies of appropriation', in contrast, there is a division of labour, and a surplus is produced that is appropriated by a ruling class: those who labour are directed by someone else, such that intellectual and manual labour are divided. Hence it cannot be the labour process that binds these class societies; rather, the social synthesis is effected by the private exchange of commodities between individual proprietors. To facilitate commodity exchange, money is invented as the universal abstraction, equivalent to every possible commodity. It is on the basis of the real abstractions of commodity exchange that the capacity for abstract thought can arise.

When a commodity is exchanged, abstraction necessarily takes place. By positing an equivalence between two different objects we abstract from their actual, physical qualities: the exchange-value of the commodity is abstracted from its use-value. This is a real abstraction because it takes place in our actions and not in our minds: when we exchange, what we are thinking about is the use-value of the commodities exchanged (i.e. the qualitative properties of the object), but the real practice of exchange takes place in terms of exchange-value. In effect, exchange has the function of separating human consciousness from its actions: " $\mathrm{t}]$ he action alone is abstract. The abstractness of their action will, as a consequence, escape the minds of the people performing it. In exchange, action is social, the minds are private'. ${ }^{\text {lii }}$ Because this real abstraction occurs first in social practices and not in the intellect, it can be said that abstraction precedes and is reflected in conceptual thought. The emergence of conceptual cognition reflects the abstract and universal character of commodity exchange as a non-empirical form, one which developed in the practices of the market rather than in thought.

The fact that abstract cognition first appeared in classical Greece can thus be explained for SohnRethel by the development in classical Greece of coinage as the primary means of commodity exchange. The Greek conceptualization of Being as something that is unchanging, timeless, nonempirical, and absolute is premised on the use of money as a timeless and immutable substance: 
'something real and yet detached from all and every sense-quality by which reality is real to us'. xliii The Greeks' development of mathematics - the most abstract form of thinking we have - went hand in hand with their division of labour and the development of money. Although the ancient Egyptians may have used a rudimentary form of geometry to help make their pyramids, their division between mental and manual labour remained limited: Egyptian 'geometry' was tied to a specific manual skill (the use of ropes to calculate lengths and angles) and a specific practice (building pyramids). It was only in classical Greece that there occurred the development of what we know as geometry: a purely abstract form of thought detached from and independent of all manual practices and operations. It was only when manual and mental labour were separated and the social synthesis was effected by commodity exchange that the abstractions of mathematics became possible. The growth of relations of commodity exchange among private owners both facilitated and called for an increasingly sophisticated and abstract mathematics. ${ }^{\text {xliv }}$ The manual operation of measure became subordinated to the act of pure thought directed to grasping the laws of abstract space over and above any particular practical task. Arising on the basis of a division between mental and manual labour, conceptual abstraction then consolidated and entrenched that division by reconstituting the relation between thought and manual labour in terms of abstract concepts.

Using this framework, Sohn-Rethel traces the development of knowledge from antiquity, through the medieval period to the rise of merchant capital and the development of industrial capital. With the emergence of capitalism, the separation of manual from mental labour becomes stark. Whereas the artisan production of the middle ages depended on the practical 'know-how' of independent producers, capitalism requires the destruction of handicraft and the submission of workers to a selfoperating, automated production process dominated by machinery: production is controlled through both economic abstractions and the ideal abstractions of science. ${ }^{\text {xlv }}$

Automation and the correlative historical necessity of modern science produce a technology that is no longer dependent upon the knowledge of the workers. The modern science which supports and reflects the material transformation to capitalist production is defined by the revolutions marked by the discovery of the laws of inertial motion which Sohn-Rethel, in perhaps his most tenuous claim, derives from the pattern of motion constituted in the real abstractions of capitalist commodity exchange. ${ }^{\text {xlvi }}$ That is, the movement of the commodity in an absolutely abstract time-space occurs in economic life without being perceived by the mind and, in turn, inaugurates forms of mathematical 
relations to nature whereby the movement of non-empirical concepts nevertheless 'give such invaluable services in the investigation of nature'. xlvii

The cognitive abstractions which Newtonian physics inaugurates and the division of industrial labour which it supports and grounds is philosophically reflected first in Descartes, but most forcefully in the Kantian a priori. For it is transcendental idealism most of all that singles out 'a part of our being which is underivable from our physical and sensorial nature' and according to which we relate to nature not as it is but only as it is mediated 'for us'. xlviii Knowledge of nature is now absolutely divorced from any form of manual labour and is contained only in a 'pure intellect' which mirrors the abstraction of exchange-value from use. With Kant, and the philosophical epistemology grounded upon an ontological structure innate to man that he inaugurates, the reversal of manual and intellectual labour is complete. Now the sensual and sensible is nothing more than the possibility of error while only the abstractions of the intellect can provide any access to truth though this is a truth that is always mediated by the finite capacity of the subject. The public freedom that Kant then demands for this subject is a freedom that implicitly veils and thus enshrines the division of intellectual and manual labour and the separation of labour from the means of production upon which it is constituted. The conversion of the priority of intellectual over manual labour, inaugurated by the Greeks, here becomes complete.

\section{From Political Topographies to Capitalist Logics}

By locating the source of cognitive abstractions firmly in the realm of practices, Sohn-Rethel permits us to re-inscribe the relation between history and ontology in a way that differs from Laclau's articulation of real abstraction. Sohn-Rethel's argument hinges upon the fundamental methodological priority he gives to historical over ontological conditions. It is in this sense that he claims that in the work of the later Marx (and, accordingly, in his own) there are no ontological postulates - no claim to some timeless conception of Being. ${ }^{\text {xlix }}$ In Sohn-Rethel's words, 'the Marixst approach to historical reality can be understood as answering the question: what must the existential reality of society be like to necessitate such and such forms of consciousness?? The historical materialist, he argues, works backwards: he infers the material social relations which would have formed the conditions for the emergence of particular abstract concepts, truths, social hierarchies, and so on. "It is on this purely critical line of procedure, on the standards of the very concepts he is out to criticize, that [the historical materialist] establishes the determination of a given mode of 
consciousness by social existence, and thereby, as the intended result, succeeds in uncovering the true reality of that social existence". li Just as Marx worked from the concepts of his contemporary political economy to the social relations they must presume, Sohn-Rethel claims that he works from contemporary epistemological propositions. In this sense, Sohn-Rethel insists that Marx's own concepts must be affirmed as contingent, emerging out of a particular historical time and place. Such an approach allows us to trace the conditions of knowledge, without presuming to begin from a definite set of historical conditions from which we then infer forms of knowledge.

Crucially, Sohn-Rethel does not reduce thought to the topographical, economically determinist visions of Engels or Plekhanov, whereby consciousness is reduced to the status of an objective reflection of an economic base. Such a schema already presumes a universal form of base and superstructure wherein a narrowly defined 'economic' sphere determines the contents of thought. lii In contrast, Sohn-Rethel's theory of real abstraction seeks to investigate the forms of consciousness itself.

This is not to say that Sohn-Rethel's analysis is without problems. As we have seen, he locates the origins of real abstraction in the sphere of exchange. This is an unusual move, given the primacy accorded by Marxism to production over exchange. For Marx, the whole basis of exchange is the abstract labour that exists only under capitalism and which Sohn-Rethel purposely ignores. ${ }^{\text {liii }}$ In contrast to Sohn-Rethel, what distinguishes capitalism for Marx is not commodity exchange, nor the division of mental and manual labour within production; it is rather that the goal of the capitalist production process is not the production of use-values by concrete labour but the production of value by abstract labour. ${ }^{\text {liv }}$ Nonetheless, we maintain that Sohn-Rethel's analysis is helpful, both for elucidating the concept of real abstraction as an alternative to the kind of intellectual abstraction upon which Laclau relies, and for his focus on the division between mental and manual labour

Following this latter line of argument in particular would enable us to investigate the specific abstractions that dominate us today and to understand why there has been a shift away from a topographical analytic towards a different analytic of social logics. Whereas Laclau formulates this shift from topography to logics in terms of the historical manifestation of an ontology that was always-already immanent, we can make use of Sohn-Rethel's framework to help us understand it in terms of historical changes to the division of mental and manual labour, and capitalism more broadly. 
Though we do not propose to develop the argument fully here, we might speculate that a topographical analytic - in which the level of the economic is separated from that of consciousness - would have had political salience and purchase in an era of Taylorist production in which there was a separation within the production process between manual labour and the higher level cognitive activities whereby that manual labour was organised and managed. In contrast, with the emergence in recent decades of post-Taylorist and post-Fordist forms of production, the division of mental and material labour is undergoing reconfiguration. For instance: in certain sectors the function of intellectual labour is increasingly incorporated directly into the technological process of production itself; automation and computerisation have expanded to govern a broadening array of processes of labour and exchange; and expanding use of mechanisms of dispossession such as intellectual property regimes has entailed an extension of the commodification of the infrastructure of human existence. ${ }^{\text {lv }}$ In short, the control of manual by mental labour is undergoing operative, spatial, and scalar transformations such that the topographical schema of social struggle that made sense under Taylorist conditions of production is now becoming increasingly obsolete.

This admittedly brief analysis suggests that that the eventual decline of this orthodox (topographical) Marxist perspective need not be understood as confirming the derivative nature of the category of production to political theorising as Laclau argues. That is, rather than looking to the inevitable decline of economically determinist versions of Marxism as confirmation of some more 'foundational' and seemingly a-historical political axiom or principle, acknowledging the material conditions of political theorising involves the refusal of excluding the category of production from attempts to theorise the conditions of social struggle in the present. This in turn implies that any emancipatory political theorization of organizational form and content must begin by reckoning with the extent to which contemporary capital subsumes social existence.

We suggest that situating the conditions of cognitive abstractions in part in contemporary material practices and, in particular, in the abstractions by which capitalism governs social life (primarily the abstraction by the commodity) permits the materialist conception of real abstraction to account for specific historical transformations of epistemological categories. Moreover, contra Laclau, it implies that understanding political possibilities in the present begins with the analysis of the social logics of contemporary capitalism which condition those possibilities. While we do not intend to undertake it 
here, such an analysis would have to confront (though this is by no means an exhaustive list): logics of debt, precarity, flexibility and the consequent transformations to the wage relation; logics of dispossession and financialisation, of the uneven nature of these processes as reflective of the nature of private property in the present; the apparent exhaustion of the geographical expansion of capitalist accumulation of biospheric wealth; and the crisis of capital's ability to reproduce both labour and itself.

As Alberto Toscano has argued, any attempt to transform our political abstractions which does not fully and formally grasp their 'embeddedness in mechanisms of social reproduction' overlooks the profound challenges that transforming them entails. ${ }^{\text {lvi }}$ To fail to recognise the extent to which our own social struggles are conditioned, at least in part, by contemporary logics of capitalism is at risk of naturalising or even valorising those very logics. Finally, a material analysis of abstraction permits locating the criteria for our political concepts not in ontological terms as the failure or success in acknowledging the inherent contingency of any social order or discourse (as in Laclau's work), but in the changing nature of contemporary social logics upon which they ought to give us cognitive purchase. Without such an analysis we risk misunderstanding the conditions in which we struggle in the present, especially if we seek to sustain that struggle in drawing upon some a priori conception of generalised antagonism.

i Oliver Marchart, Post-Foundational Political Thought: Political Difference in Nancy, Lefort, Badiou and Laclau (Edinburgh: Edinburgh University Press, 2007). See also Alain Badiou, Saint Paul: The Foundations of Universalism, trans. Ray Brassier (Stanford, CA: Stanford University Press, 2003); Étienne Balibar, Politics and the Other Scene (London: Verso, 2002); Jacques Rancière "Post-Democracy, Politics, Philosophy: An Interview with Jacques Ranciere," Angelaki 1 (1996): 171-178; Slavoj Žižek, The Ticklish Subject: The Absent Centre of Political Ontology (London: Verso, 1999). 
ii On this point see Paul Rekret, "Generalised Antagonism and Political Ontology," in Radical Democracy and Collective Movements Today: The Biopolitics of the Multitude Versus the Hegemony of the People, ed. Alexandros Kioupkiolis \& Giorgios.Katsambekis (London: Ashgate, 2014).

iii On wider materialist debates over abstraction, see Alfred Schmidt, The Concept of Nature in Marx, trans. B. Fowkes (London: New Left Books, 1971); Fredric Jameson, The Political Unconscious: Narrative as a Socially Symbolic Act (Ithaca, NY: Cornell University Press, 1981); Henri Lefebvre, The Production of Space, trans. Donald Nicholson-Smith (Oxford: Blackwell, 2000); Louis Althusser, For Marx, trans. Ben Brewster (London: Verso, 2005).

iv Ernesto Laclau and Chantal Mouffe, Hegemony and Socialist Strategy: Towards a Radical Democratic Politics (London: Verso, 1985), viii, 18, 159-171; Ernesto Laclau, New Reflections on the Revolution of Our Time (London: Verso, 1995), 45, 52-9, 90, 97-8; Ernesto Laclau, On Populist Reason (London: Verso, 2005), 2302; Ernesto Laclau, "Identity and Hegemony: The Role of Universality in the Constitution of Formal Logics," in Judith Butler, Ernesto Laclau, and Slavoj Žižek, Contingency, Hegemony, Universality: Contemporary Dialogues on the Left (London: Verso, 2000), 52, 53.

v Laclau, "Identity and Hegemony," 50.

vi Ibid., 86-7, n.8.

vii In this sense this article follows and is inspired by a resurgence of interest in Sohn-Rethel's work and the category of abstraction in recent years. In particular, see Alberto Toscano, "The Culture of Abstraction," Theory, Culture \& Society 25 (2008): 57-75; Benjamin Noys, The Persistence of the Negative: A Critique of Contemporary Continental Theory (Edinburgh: Edinburgh University Press, 2010); Anselm Jappe, preface to La Pensée-marchandise, by Alfred Sohn-Rethel, trans. Anselm Jappe (Paris: Editions du Croquant, 2010); George Tsogas, "The Commodity Form in Cognitive Capitalism," Culture and Organization 18 (2012): 37795.

viii Laclau, New Reflections on the Revolution of Our Time, 27, 33, 35, 61; Laclau, "Identity and Hegemony," $58,71,85$.

ixLaclau defines social 'logics' not merely as the rules of social systems, but as the types of relations between social entities which make possible the actual operation of social systems. In other words, the social logics he articulates refer both to an ontic and an ontological dimension, as we illustrate below. See Ernesto Laclau, "Constructing Universality," in Judith Butler, Ernesto Laclau, and Slavoj Žižek, Contingency, Hegemony, Universality: Contemporary Dialogues on the Left (London: Verso, 2000), 283-4.

x $\quad$ Laclau, On Populist Reason; Laclau, "Identity and Hegemony".

xi Laclau, "Constructing Universality," 303.

xii $\quad$ Laclau, On Populist Reason, 131; Laclau, "Constructing Universality," 304.

xiii Laclau, New Reflections on the Revolution of Our Time, 27, 33, 35, 61; Laclau, "Identity and Hegemony," $58,71,85$.

xiv Laclau, New Reflections on the Revolution of Our Time, 9; Laclau, On Populist Reason, 149.

xv Laclau, "Identity and Hegemony," 57-8.

xvi Laclau, "Constructing Universality," 300.

xvii Laclau, New Reflections on the Revolution of Our Time, 41-59; Laclau, "Identity and Hegemony," 57-8; Laclau, On Populist Reason, 229-232.

xviii Slavoj Žižek, “Class Struggle or Postmodernism? Yes, please!” in Judith Butler, Ernesto Laclau, and Slavoj Žižek, Contingency, Hegemony, Universality: Contemporary Dialogues on the Left (London: Verso, 2000). 
xix Ernesto Laclau, "Structure, History and the Political," in Judith Butler, Ernesto Laclau, and Slavoj Žižek Contingency, Hegemony, Universality: Contemporary Dialogues on the Left (London: Verso, 2000), 192; Ernesto Laclau, "Glimpsing the Future," in Laclau: A Critical Reader, ed. Simon Critchley and Oliver Marchart (Abingdon: Routledge, 2004), 323.

xx Laclau, "Structure, History and the Political," 201.

xxi Laclau, New Reflections on the Revolution of Our Time, 17.

xxii Ibid., 51.

xxiii Laclau, "Constructing Universality," 301.

xxiv Laclau, "Structure, History and the Political," 189, 191; Laclau, "Glimpsing the Future," 323. xxv Jameson, The Political Unconscious, 51.

${ }^{x x v i}$ One explanation for Laclau's reliance on intellectual rather than real abstractions may be the influence of Althusser upon his work. For Althusser, drawing upon Marx's methodological text the "1857 Introduction" (albeit in an idiosyncratic and controversial manner), the distinction between the "abstract" and the "concrete" is a purely intra-theoretical distinction: abstraction is something that pertains to and takes place within theoretical practice and has nothing to do with the real abstractions of commodity production and exchange. See for example the essay "On the Materialist Dialectic" in Althusser, For Marx.

xxvii Norman Geras, Discourses of Extremity: Radical Ethics and Post-Marxist Extravagances (London: Verso, 1990), 99. See also Terry Eagleton, Ideology: An Introduction (London: Verso, 1990), 222; Ellen Meiksins Wood, The Retreat from Class: A New 'True' Socialism (London: Verso, 1998).

xxviii Laclau, New Reflections on the Revolution of Our Time, 102, 103-6.

xxix Ibid., 108.

xxx Louis Althusser, Philosophy and the Spontaneous Philosophy of the Scientists \& Other Essays, trans. Gregory Elliott (London: Verso, 1990), 130-1.

xxxi Geoff Boucher, The Charmed Circle of Ideology.

xxxii Bruno Bosteels, Badiou and Politics (London: Duke University Press, 2011), 116; Žižek, "Class Struggle or Postmodernism?"

xxxiii Laclau, New Reflections on the Revolution of Our Time, 186.

xxxiv $\quad$ Bosteels, Badiou and Politics, 116.

xxxvOn the reception of Sohn-Rethel and the centrality of his work to the study of real abstraction, see Toscano, "The Culture of Abstraction"; Alberto Toscano, "The Open Secret of Real Abstraction," Retbinking Marxism 20 (2008): 273-87; George Caffentzis, In Letters of Blood and Fire: Work, Machines, and the Crisis of Capitalism (Oakland, CA: PM Press, 2013), 164-175; Moishe Postone, Time, Labor, and Social Domination: A Reinterpretation of Marx's Critical Theory (Cambridge: Cambridge University Press, 1993); Alberto Toscano, "Materialism without matter: abstraction, absence and social form," Textual Practice 28 (2014): 1221-1240. See also the edition of Endnotes on "Misery and the Value Form", http://endnotes.org.uk/issues/2. (Accessed 5, March 5, 2014.)

xxxvi Alfred Sohn-Rethel, Intellectual and Manual Labour: A Critique of Philosophical Epistemology

(London: MacMillan, 1978), 37.

xxxvii Ibid., xi.

xxxviii Toscano, "The Open Secret of Real Abstraction," 281.

xxxix Sohn-Rethel, Intellectual and Manual Labour, 4. 
$\begin{array}{ll}\text { xl } & \text { Ibid., } 5 . \\ \text { xli } & \text { Ibid., } 85 . \\ \text { xlii } & \text { Ibid., 28-9. }\end{array}$

xliiilbid., 64, 59. Sohn-Rethel's intuitions regarding the conditions of the emergence of abstract cognition in Ancient Greece are supported by Richard Seaford, Money and the Early Greek Mind: Homer, Philosophy,

Tragedy (Cambridge: Cambridge University Press, 2004). See also Richard Seaford, "Monetisation and the

Genesis of the Western Subject," Historical Materialism 20 (2012): 78-102.

xliv Sohn-Rethel, Intellectual and Manual Labour, 101.

xlv Ibid., 118.

xlvi Ibid., 128.

xlvii Ibid., 127.

xlviii Ibid., 36 .

xlixOne finds similar claims across a variety of Marxian theorists who emphasis that Capital is a critique of political economy and, as such, does not posit an ontology of its own. See, for example, Schmidt, The Concept of Nature in Marx; Daniel Bensaï, Marx for Our Times: Adventures and Misadventures of a Critique, trans. Gregory Elliot (London: Verso, 2002); Michael Heinrich, Introduction to the Three Volumes of Karl Marx's Capital, trans. Alexander Locascio (New York, NY: Monthly Review Press, 2012).

$1 \quad$ Sohn-Rethel, Intellectual and Manual Labour, 197.

li Ibid., 195.

lii Jappe, preface to La Pensée-marchandise.

liii Sohn-Rethel, Intellectual and Manual Labour, 34.

liv For a (sympathetic) critique of Sohn-Rethel along these lines, see Anselm Jappe, "Sohn-Rethel and the Origin of 'Real Abstraction': A Critique of Production or a Critique of Circulation?" Historical Materialism 21 (2003): 3-14.

lv On the changing role of intellectual labour in production see for instance, Yann Moulier Boutang, Cognitive Capitalism (Cambridge: Polity, 2011); Michael Hardt \& Antonio Negri, Empire (Cambridge, MA: Harvard University Press, 2000). For a critique of this argument see Aufheben, "Keep on Smiling: Questions of Immaterial Labour," Aufheben 14 (2006): 23-44; David Campfield, "The Multitude and the Kangaroo: A Critique of Hardt \& Negri's Theory of Immaterial Labour," Historical Materialism 15 (2007): 21-52; Steve Wright, "Reality Check: Are We Living In An Immaterial World?" Mute 2 (2005) http://www.metamute.org/editorial/articles/reality-check-are-we-living-immaterial-world (Accessed 14 September 2014). On the automation of finance see Donald MacKenzie, "A Sociology of Algorithms: High-Frequency Trading and the Shaping of Markets," Working Paper. chromeextension://oemmndcbldboiebfnladdacbdfmadadm/http://www.maxpo.eu/Downloads/Paper_Donald MacKenzie.pdf (Accessed October 2014). On the expansion of commodification see for instance, Kathleen McAfee, "Neoliberalism on the Molecular Scale: Economic Reductionism in Biotechnology Battles," Geoforum 34 (2003): 203-19.

lvi Toscano, "The Culture of Abstraction". 